九州大学学術情報リポジトリ

Kyushu University Institutional Repository

\title{
Classification of the Constituents of Citrus Juice Residue by a Wet-Grinding Process
}

\section{Furuta, Shu}

Laboratory of Food Processing, Faculty of Agriculture, Kyushu University

Hayakawa, Isao

Laboratory of Food Processing, Faculty of Agriculture, Kyushu University

Fujio, Yusaku

Laboratory of Food Processing, Faculty of Agriculture, Kyushu University

https://doi.org/10.5109/23892

出版情報：九州大学大学院農学研究院紀要. 34 (1/2)，pp.101-106，1989-11. Kyushu University バージョン：

権利関係 : 


\title{
Classification of the Constituents of Citrus Juice Residue by a Wet-Grinding Process
}

\author{
Shu Furuta, Isao Hayakawa and Yusaku Fujio \\ Laboratory of Food Processing, Faculty of Agriculture, \\ Kyushu University 46-09, Fukuoka 812, Japan \\ (Received June 29, 1989)
}

\begin{abstract}
Biomass are consisted of various constituents with different chemical and physical characteristics It seems that a wet-grinding process can effectively separate components which intricately construct the tissue. Then the waste residue of Satsuma mandarin fruit juice was ground under the existence of water using a commercially available grinder. Since the citrus residue is commonly consisted of fibrous solids, non-fibrous solids and water soluble solids, it was confirmed that each of these constituents could be separated with a wet-grinding process. The fibrous and non-fibrous portions of the ground residue under suitable operating conditions were classified into coarse and fine fractions by a wet screening method. In the case of peeling of Satsuma mandarin juice residue, water soluble pectic substances were more effectively recovered in the liquid fraction in wet-grinding comparing with a conventional acid-extraction method.
\end{abstract}

\section{INTRODUCTION}

Biomass such as plant, plant seed, meat have been often processed with grinders in food industries (Matsubara, 1983 and Ishihara, 1987), for example, separation of wheat gluten from wheat (Slatter and Langford, 1944) and extraction of leaf protein (Edwards et al., 1978 ;Carroad et al., 1981). In spite of many actual industrial applications, almost no fundamental research have been done on wet-grinding of biomass. In the production of citrus fruit juice, waste residue comprised of peel, pulp, rag and seeds is created as an almost valueless by-product. These components are not only made of physically different in tissue structures but also contain different water soluble components (Sinclair, 1984). For example, some tissues are brittle in its nature while others are ductile. The juice residue contains pectic substances as its major available components, and the pressate of the residue has been available as the citrus molasses (Sinclair, 1984). Recently, water insoluble solids in the residue have also been utilizable as the citrus flour and dietary fiber as described by Sinclair (1984).

A study on wet-grinding of Satsuma mandarin (Citrus unshu Marc.) juice residue and on subsequent separation was carried out in order to investigate the effects of wet-grinding on biomass. As a result, it was discovered that the water insoluble portion could be separated into coarse fibrous fraction with ductile nature and nonfibrous particles by a wet-grinding process. It was also discovered that the water soluble pectic substances as alcohol insoluble solid (AIS) were effectively isolated from the liquid fractions. 


\section{MATERIALS AND METHODS}

\section{R aw biomass}

The residue of Satsuma mandarin juice with $79 \%$ moisture content (wet basis) was used as a raw material for the wet-grinding trials. The citrus juice residue contained peel, pulp and rag, but did not contain seeds.

\section{Grinder and grinding method}

The grinder used for this experiment was a double disk attrition mill (single runner type) with $\mathbf{0 . 7 5} \mathrm{Kw}$ connected horse power. The rotating disk was made of cast-aluminium material covered with 170 mesh sharp edged diamond particles (Noritake Diamond Tool Co., Nagoya, Japan). The stationary disk was made of 80 mesh emery disk. The diameters of these disks were $190 \mathrm{~mm}$. The gap between the stationary disk and the rotating disk was adjusted manually based on an arbitrary scale from 0 to 100 . Three trials were carried out at different gap-distances between the two disks, which corresponded to coarse, medium and fine grindings.

Before feeding to the grinder, the citrus juice residue was cut not to be larger than $5 \mathrm{~mm}$ in size. A five hundred gram of precut sample (wet basis) was fed to the grinder with 1 liter of deionized water.

\section{Analysis of ground residue}

The ground residue from the grinder was first centrifuged in order to separate the liquid portion. The pectic substances were obtained as alcohol insoluble substances (AIS, final concentration of ethanol ; $90 \%$ ) by a alcohol-precipitation. The alcohol precipitate was dried at $60^{\circ} \mathrm{C}$ in a vacuum oven and weighed. The concentration of pectic substances contained in the centrate was determined on the basis of the dried amount of alcohol insoluble substances.

The centrifuged solids were wet-fractionated with woven Nylon screens (Swiss Silk Bolting Cloth Co., THAL-SG, Switzerland). The nominal openings of these screens were 5 (HD5), 50 (DIN), 100 (13 NXX), 200 (7 NXX) and 500 (38 NGG) microns. The resultant four fractions were weighed after drying at $60^{\circ} \mathrm{C}$ in a vacuum oven and the contents of fiber and acid hydrolyzable sugars were determined on the four fractions.

The moisture contents of raw citrus juice residue and water insoluble fractions were determined by drying them at $60^{\circ} \mathrm{C}$ in a vacuum oven. The contents of fiber and acid hydrolyzable sugars were analyzed by the standard method commonly used in food analysis.

\section{RESULTS AND DISCUSSION}

\section{$M$ aterial balance of wet-grinding}

The wet-grinding trials were carried out at three different grinder-gap openings. Although the differences in gap openings between three runs were not so great, distinctively different products : coarse, medium and fine were obtained. Table 1 shows the material balance for each trial. In Table 1, the water soluble solid contents were determined through evaporation on a boiling water bath. As Table 1 showed, the 
Table 1. Material balance of wet-ground Satsuma Mandarin juice residue.

\begin{tabular}{lccc}
\hline & Insoluble Solid & Soluble Solid & Recovery \\
Grinding scale & $\mathrm{g}(\%)$ & $\mathrm{g}(\%)$ & $\mathrm{g}(\%)$ \\
& $67.3(64.5)$ & $31.9(30.6)$ & $99.2(95.0)$ \\
Coarse & $68.9(66.0)$ & $36.4(34.9)$ & $105.3(100.9)$ \\
Medium & $75.8(72.6)$ & $28.5(27.3)$ & $104.3(99.9)$ \\
Fine & &
\end{tabular}

Initial dry weight of citrus residue was $104.4 \mathrm{~g}$.

Table 2. Summary of wet-grinding trials.

\begin{tabular}{|c|c|c|c|c|c|c|}
\hline $\begin{array}{c}\text { Grinding } \\
\text { scale }\end{array}$ & $\begin{array}{l}\text { Opening/ } \\
\text { Average } \\
(\mu \mathrm{m}) /(\mu \mathrm{m})\end{array}$ & $\begin{array}{l}\text { Percent } \\
\text { fraction } \\
\quad(\%)\end{array}$ & $\begin{array}{c}\text { Weight/ } \\
\text { Cumulative } \\
(\mathrm{g}) /(\mathrm{g}) /(\%)\end{array}$ & $\begin{array}{l}\text { Crude } \\
\text { fiber } \\
(\%)\end{array}$ & $\begin{array}{c}\text { Sugars } \\
(\%)\end{array}$ & $\begin{array}{l}\text { AIS in } \\
\text { liquid } \\
(\%)\end{array}$ \\
\hline Coarse & $\begin{array}{r}5-50 / 27.5 \\
50-100 / 75.0 \\
100-200 / 150.0 \\
200-500 / 350.0\end{array}$ & $\begin{array}{r}35.8 \\
4.4 \\
10.9 \\
48.9\end{array}$ & $\begin{array}{r}24.1 / 67.3 / 100.0 \\
3.0 / 43.2 / 64.2 \\
7.3 / 40.2 / 59.7 \\
32.9 / 32.9 / 48.9\end{array}$ & $\begin{array}{r}1.5 \\
28.6 \\
28.5 \\
25.2\end{array}$ & $\begin{array}{l}41.5 \\
37.8 \\
35.8 \\
35.8\end{array}$ & 0.81 \\
\hline Medium & $\begin{array}{r}5-50 / 27.5 \\
50-100 / 75.0 \\
100-200 / 150.0 \\
200-500 / 350.0\end{array}$ & $\begin{array}{l}47.5 \\
10.9 \\
19.6 \\
22.0\end{array}$ & $\begin{array}{r}32.7 / 68.9 / 100.0 \\
7.5 / 36.2 / 52.5 \\
13.5 / 28.7 / 41.7 \\
15.2 / 15.2 / 22.1\end{array}$ & $\begin{array}{r}5.9 \\
29.5 \\
27.6 \\
22.9\end{array}$ & $\begin{array}{l}46.8 \\
34.0 \\
35.4 \\
37.4\end{array}$ & 0.78 \\
\hline Fine & $\begin{array}{r}5-50 / 27.5 \\
50-100 / 75.0 \\
100-200 / 150.0 \\
200-500 / 350.0\end{array}$ & $\begin{array}{r}52.8 \\
19.6 \\
24.3 \\
3.4\end{array}$ & $\begin{array}{r}40.0 / 75.8 / 100.0 \\
14.8 / 35.8 / 47.2 \\
18.4 / 21.0 / 27.7 \\
2.6 / 2.6 / 3.4\end{array}$ & $\begin{array}{r}4.3 \\
20.5 \\
23.9 \\
21.0\end{array}$ & $\begin{array}{l}36.4 \\
35.9 \\
36.7 \\
29.2\end{array}$ & 0.88 \\
\hline
\end{tabular}

There was no particle larger than $500 \mu \mathrm{m}$ for all grinding runs.

overall recovery for each trial was nearly $100 \%$ based on the original sample weight of $104.4 \mathrm{~g}$ (as dried matter, corresponds to $500 \mathrm{~g}$ of wet feed).

\section{Differential screen analysis for water insoluble solids}

The water insoluble fractions obtained by the three trials shown in Table 1 were classified with a wet screening. The results were shown in Table 2. Table 3 shows the results for crude fiber and total sugar analysis on each fraction, In the coarse grinding trial for example, the insoluble solids fraction between 5-50 microns was $35.8 \%(\mathrm{w} / \mathrm{w})$ out of $67.3 \mathrm{~g}$ total insoluble solids, and it contained only $1.5 \%$ crude fiber. In contrast, the fraction between 200-500 microns contained 25.2\% crude fiber. Crude fiber contents in 5-50 micron fractions for coarse, medium and fine grinding trials were significantly lower than that of other fractions. Since the tissue of citrus juice residue is consisted of ductile substances as fiber and brittle substances as sugar, it is thought that brittle substances are mainly classified into 5-50 micron fractions while ductile substances are mainly classified into fractions greater than 50 microns. It therefore can be concluded that biomass can be effectively separated with a wet-grinding process.

\section{Average particle size of citrus juice residue treated with the wet-grinder}




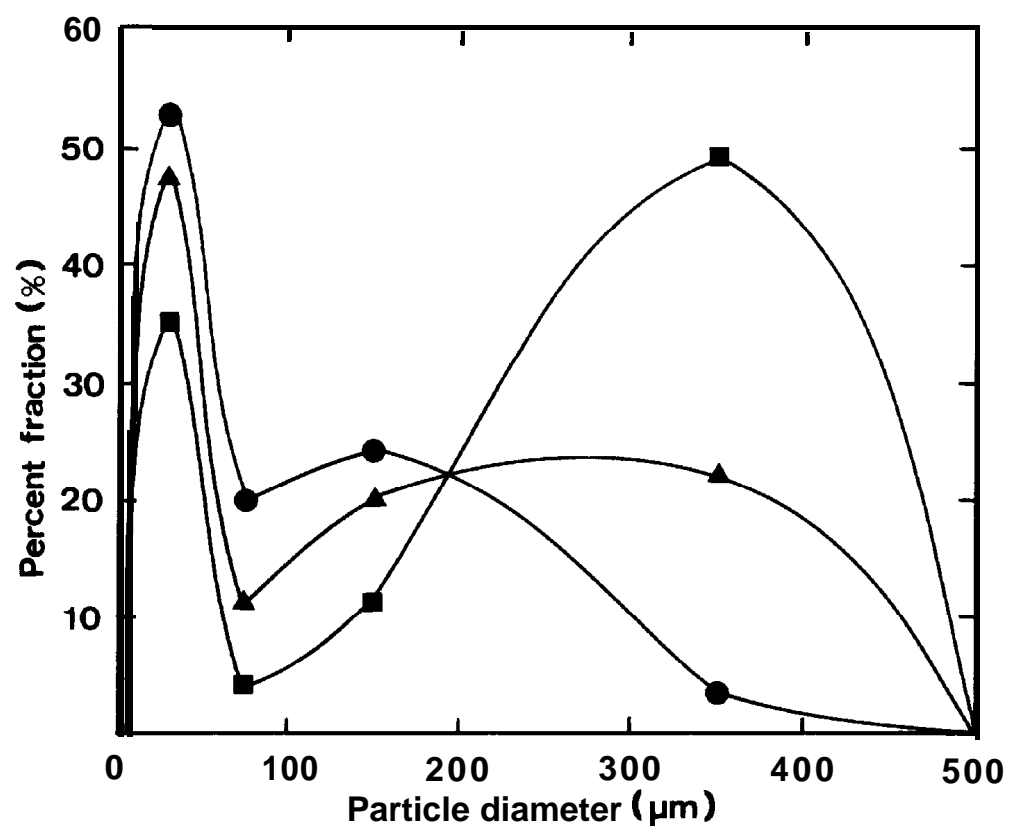

Fig. 1. Particle size distribution of flour obtained by wet-grinding of Satsuma Mandarin residue.

- : Coarse grinding run

$\Delta$ : Medium grinding run

: Fine grinding run

Figure 1 illustrates the particle size distributions for coarse, medium and fine grinding trials. In Fig. 1, the average particle diameter is defined as the arithmetic average of the nominal incremental dimensions of each screen. Figure 1 shows that 5 -50 and ZOO-500 micron fractions in coarse grinding are two dominant fractions while 50-100 micron fraction is the minimum fraction. The existence of the two peaks in the particle size distribution curve may be explained through the grinding actions of biomass which consisted of ductile and brittle substances. Brittle substances in biomass have a greater tendency to form fine particles compared tó ductile substances. As grinding gap is narrowed from coarse to fine, the amount of ZOO-500 micron fraction was decreased while the amounts of 5-50 and 50-100 micron fractions were increased. In spite of the increase in the amount of 5-50 micron fraction, crude fiber content in this fraction did not increase significantly. The above indicates that particle size of the fibrous materials (ductile substances) in citrus juice residue are difficult to reduce below 50 microns by the wet-grinding method.

Based on differential screen analysis shown in Table 1, particle cumulative size distribution is plotted in Fig. 2. From particle cumulative size distribution, the average particle diameters which correspond to $50 \%$ cumulation for coarse, medium and fine grinding trials were found to be 350, 90 and 60 microns respectively. As a result, the average particle diameter in Fig. 2 is significantly affected by the small change in the grinding gap. 


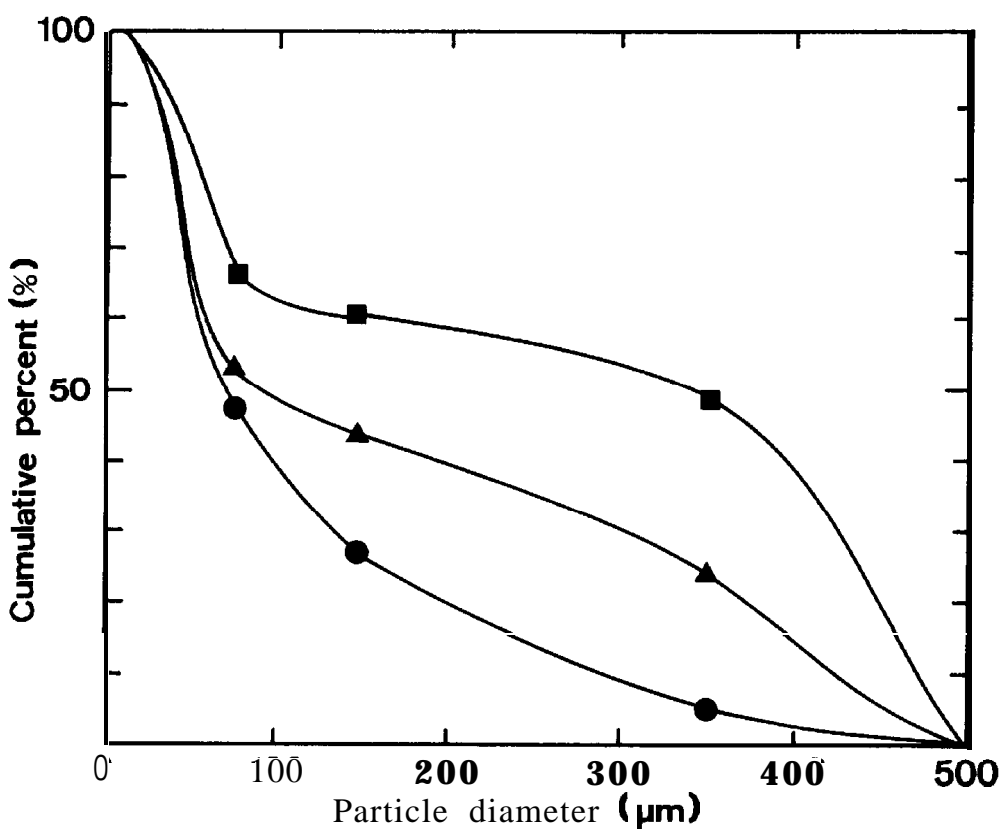

Fig. 2. Cumulative particle size distribution of flour obtained by wet-grinding of Satsuma Mandarin residue.

口: Coarse grinding run

A: Medium grinding run

- : Fine grinding run

AIS extraction by wet-grinding

As shown in Table 2, the liquid fractions obtained after the grinding operation contained $0.81,0.78$ and $0.88 \%(\mathrm{w} / \mathrm{v})$ for coarse, medium and fine grinding trials respectively. These AIS contents were about 2 times greater than the typical AIS content obtained by the conventional acid-extraction method (Kausar and Nomura, 1980). Such an AIS content in the liquid fraction indicates that the processing with wet-grinding is one of effective methods for production of pectin from citrus juice residue.

Efficiency of separating crude fiber

Based on the particle size distribution and fiber contents data as shown in Table 1, the amounts of crude fiber in each screen fraction for coarse, medium and fine grinding trials were calculated in Table 3. The efficiency of crude fiber separation was defined as the percentage of the amount of the total crude fiber in 50-500 micron fraction against the crude fiber content in the feed. The 5-50 micron fraction contained a significant amount of citrus flour high in sugar content and low in fiber content. It can be concluded that the constituents of which biomass have different chemical and mechanical properties can be effectively separated by noble wet-grinding. 
Table 3. Separation efficiency of crude fiber in insoluble solids of Satsuma Mandarin juice residue by wet-grinding.

\begin{tabular}{lrccc}
\hline Grinding scale & Fraction & Weight & Crude fiber & $\begin{array}{c}\text { Percent of } \\
\text { crude fiber } \\
\text { (\%) }\end{array}$ \\
\hline Coarse & $(\mu \mathrm{m})$ & $(\mathrm{g})$ & $(\mathrm{g})$ & $\mathbf{2 . 6}$ \\
& $\mathbf{5 - 5 0}$ & $\mathbf{2 4 . 1}$ & $\mathbf{0 . 3}$ & $\mathbf{9 7 . 4}$ \\
Medium & $\mathbf{5 0 - 5 0 0}$ & $\mathbf{4 3 . 2}$ & $\mathbf{1 1 . 2}$ & 17.4 \\
& $\mathbf{5 - 5 0}$ & 32.7 & 1.9 & 82.6 \\
Fine & $50-500$ & 36.2 & 9.0 & 19.2 \\
& $5-50$ & 40.0 & 1.9 & 80.8 \\
\hline
\end{tabular}

\section{REFERENCES}

Carroad, P. A., H. Anaya-Serrano, R. H. Edwards and G. 0. Kohler 1981 Optimization of Cell Disruption for Alfalfa Leaf Protein Concentration (Pro-Xan) Production. J. Food Sci., 46 : 383390

Edwards, R. H., D. de Fremery, B. E. Mackey and G. 0. Kohler 1978 Factors Affecting Juice Extraction and Yield of Leaf Protein Concentrate from Ground Alfalfa. Transactions of the ASAE, 21: 55-59

Ishihara, R. 1987 Grinding of special food materials. New Food Industry, 29 (12) : 24-28 (in Japanese)

Kausar, P. and D. Nomura 1980 A New Approach to Pectin Manufacture by Copper Method. $J$. Fac. Agr., Kyushu Univ., 25: 61-71

Matsubara, T. 1983 Cryogenic Crushing of Foodstuffs. Reito, 58 : 1191-1195 (in Japanese)

Sinclair, W. B. 1984 Some Soluble and Insoluble Constituents of Citrus Fruits, The Pectic Substances, Products from Lemons and Other Citrus Fruits. In "The Lemon", University of California, California

Slatter, R. L. and C. T. Langford 1944 Wheat Starch Manufacture. Ind. Eng. Chem., $36:$ 404-408 